\title{
ANALISIS KUALITAS PELAYANAN DAN USULAN PERBAIKAN PELAYANAN TRAVEL MALANG-BANDARA JUANDA
}

\author{
MUHAMMAD NASRI \\ Bagian administrasi pembangunan Kab Malang Jalan Merdeka Timur No 3 Malang \\ E-mail: Nas1234@malangkab.go.id
}

\begin{abstract}
The existence of travel agency in Malang is viewed as strategic business because it could replace the personal vehicle for heading toward Juanda Airport in Surabaya since Malang itself didn't have any international standard airport so the member of the society who wants to get in or out from Malang using aeroplane should go to Juanda Airport in Surabaya. This would cause the competition among travel services in Malang become more competitive by the emerging of new travel agencies. In case the Kirana Travel Agency would maintain its existence, they need to make efforts to improve its service quality. Therefore, it require an experiment to found out what kind of service attributes that wanted by the customer and how does the gap between the perception and consumer expectancy toward the ongoing service quality. One of the planning method that can be use to translate the need of the consumer into action plan for the company is QFD. This step would be use as evaluation tool and planning on service quality improvement. To sharpened identification of the service quality attributes then the QFD approach integrated with Servqual approach. During the Servqual review, it is found eight service attributes that need to be fixed which is: information accuracy given by the employees, the precise time on pick-up, good reaction of the employees in handling consumer complaints, the availability of health and safety facility (First aid box, fire extinguisher, etc), travel order confirmation, driver that should consistently being polite toward the consumer, easy access to be called and gain information from the operator and travel prices. While the technical response prioritized to be fix and to be use for fulfilling the consumer satisfaction in Kirana Travel from the HOQ analysis includes: employees training (contributed 23.43\%), providing special number for complain support (contribution 13.71\%), fixing the communication inter-department inside the company (contribution 11.84\%), fixing the pick-up schedule system (contribution 8.83\%). The improvement proposal given by the researcher is to improve the new and old employee training so it could bring better performance in order to fulfilling the consumer satisfaction.
\end{abstract}

Key words: perception, expectation, service quality, QFD, $H O Q$

\section{PENDAHULUAN}

Perkembangan pengetahuan dan teknologi menjadikan masyarakat semakin kritis dalam menyikapi persoalan kehidupan. Salah satunyaadalah semakin tingginya tuntutan untuk mendapatkan jasa yang berkualitas. Bidang transportasi merupakan salah satu bagian yang memiliki karakteristik utama memberikan pelayanan kepada konsumen. Dalam bidang jasa ini pelayanan merupakan salah satu hal yang sangat sensitif sehingga pihak perusahaan harus mengupayakan pemberian pelayanan yang sebaik-baiknya kepada pelanggan.

Pelanggan merupakan fokus utama dalam pembahasan mengenai kepuasan dan kualitas jasa. Oleh karena itu, dalam hal ini pelanggan memegang peranan cukup penting dalam mengukur kepuasan terhadap produk maupun pelayanan yang diberikan perusahaan (Lupiyoadi, 2001). Oleh sebab itu, untuk mengukur keberhasilan yang diperoleh ditentukan oleh pelanggan itu sendiri hal ini dipengaruhi dengan apa yang disampaikan pihak penyedia jasa apakah telah memenuhi harapan pelanggan.

Keberadaan perusahaan travel di Kota Malang dinilai sangat strategis karena bisa dijadikan kendaraan alternatif, pengganti kendaraan pribadi untuk menuju bandara Juanda Surabaya karena di Kota Malang sendiri belum memiliki bandara bertaraf internasional sehingga masyarakat yang ingin keluar atau masuk Kota Malang menggunakan pesawat harus melalui bandara Juanda di Surabaya.

Kondisi ini yang menyebabkan persaingan jasa travel di Kota Malang menjadi lebih kompetitif dengan banyak munculnya perusahaan jasa travel lain. Agar Perusahaan Travel "X" dapat mempertahankan eksistensinya, maka diperlukan 
usaha untuk meningkatkan kualitas pelayanannya. Sebelum meningkatkan kualitas pelayanan, terlebih dahulu perlu dilakukan pengukuran terhadap kualitas pelayanan yang ada sekarang. Oleh karena itu, perlu dilakukan penelitian untuk mengetahui bagaimana pandangan pelanggan terhadap sejauh mana pelayanan yang diberikan selama ini dan bagaimana seharusnya pelanggan diperlakukan.

Metode SERVQUAL merupakan salah satu cara untuk mengukur kepuasan pelanggan atas jasa yang diterimanya (Jiang dkk., 2003). Metode ini khusus digunakan untuk mengukur kepuasan pelanggan atas jasa yang diberikan. Dalam perkembangannya, metode SERVQUAL dapat diintegrasikan dengan melibatkan metode lainnya seperti Quality Function Deployment (QFD). QFD menggunakan format matriks untuk menangkap hal-hal yang berhubungan dan vital pada proses perencanaan. Matriks ini menggambarkan hal-hal tersebut secara terperinci yang memungkinkan pihak perusahaan untuk menganalisis informasi tersebut secara multidimensi. Hasil dari QFD memberikan prioritas perbaikan yang disertai dengan target pelayanan yang harus diberikan pada pelanggan (Cohen, L, 1995). Tujuan yang ingin dicapai dari penelitian ini adalah memperoleh atribut-atribut pelayanan yang perlu diperbaiki, merencanakan respons teknis yang digunakan untuk perbaikan berdasarkan hasil perancangan rumah kualitas (HOQ), dan mendapatkan usulan perbaikan pelayanan travel Malang-bandara Juanda.

\section{METODE}

Penentuan Atribut didapatkan dari pengamatan di lapangan, wawancara awal dengan pelanggan dan hasil diskusi dengan karyawan pihak pengelola. Dalam mengidentifikasi atribut layanan ini dicoba untuk mengaplikasikan pendekatan SERVQUAL, pemecahan (breakdown) atributlayananberpedoman pada dimensi kualitas yang telah dikembangkan (Parasuraman Amin, W. 1992), antara lain: tangibles, reliability, responsiveness, assurance, emphaty.

Setelah diputuskan bahwa untuk mendapatkan data primer dilakukan dengan cara komunikasi dengan mengajukan pertanyaan dalam kuesioner, maka langkah berikutnya adalah merancang form kuesioner. Dalam pengambilan sampel, teknik yang digunakan adalah purposive sampling, responden yang terpilih merupakan pelanggan Travel "X" yang sudah pernah menggunakan travel pesaing (Travel "X"). Langkah dalam penyebaran kuesioner adalah untuk mengumpulkan data dari responsden dengan mengisi kuesioner yang telah dirancang. Dalam pengisian kuesioner ini dilakukan secara langsung, peneliti mendampingi responsden unutk memastikan setiap pertanyaan dapat dimengerti dengan baik.

Uji validitas bertujuan untuk menunjukkan sejauh mana suatu alat pengukur mampu mengukur apa yang ingin diukur. Jika alat ukur telah dinyatakan valid, selanjutnya reliabilitas alat ukur tersebut diuji. Reliabilitas adalah suatu nilai yang menunjukkan konsistensi suatu alat pengukur didalam gejala yang sama. Uji reliabilitas digunakan untuk melihat tingkat konsistensi dari responsden. Data dikatakan validjika data memiliki nilai $r$ hitung $>\mathrm{r}$ tabel. Sedangkan data dikatakan reliable apabila nilai Cronbach Alpa > 0,6.

Selanjutnya dilakukan perhitungan SERVQUAL, dimulai dengan menghitung nilai rata-rata, skor ekspektasi dan skor persepsi layanan. Tingkat ekspektasi pelanggan adalah harapan pelanggan terhadap servis yang diberikan oleh pihak perusahaan travel "X". Sedangkan persepsi layanan pelanggan adalah pandangan atau citra pelanggan terhadap servis yang telah diberikan pihak perusahaan travel "X". Hasil perhitungan nilai persepsi dan ekspektasi akan digunakan untuk memperoleh nilai gap. Nilai gap diperoleh dari pengurangan nilai persepsi dengan ekspektasi. Pada hakikatnya pengukuran kualitas suatu jasa hampir sama dengan pengukuran kepuasan pelanggan, yaitu ditentukan oleh hasil dari nilai persepsi dan ekspektasi.

Tahap perancangan QFD Merupakan tahap akhir dalam penelitian. Menyusun customer needs (Matrik WHATs). Karena penelitian ini menggabungkan kelebihan metode Servqual dan QFD, maka dalam menyusun daftar matriks WHATs dengan memperhatikan gap kepuasan pelayanan. Jika terdapat gap bernilai (-) pada atribut layanan yang bersangkutan.

Membuat planning matrix, terdiri dari penentuan: importance to customer, customer 
satisfaction performance, competitive satisfaction performance, goal, improvement ratio, sales point, raw weight, normalized raw weight.

Menyusun daftar technical response matriks (HOWs). Respons teknis adalah spesifikasi teknis yang dimunculkan oleh tim pengembang kualitas yang digunakan untuk memenuhi keinginan/ kebutuhan pelanggan.

Mengembangkan hubungan antara Matriks WHATs dan HOWs (Relationship Matrix). Matriks ini akan memperhatikan hubungan atau sejauh mana pengaruh respons teknis yang diberikan pihak pengelola dalam memenuhi keinginan pelanggan. Matriks ini juga menunjukkan hubungan antara kebutuhan konsumen dengan respons teknis, yang digambarkan dalam bentuk simbol-simbol hubungan kuat, menengah dan lemah.

Menentukan hubungan antar Matriks HOWs (Technical Correlation). Tahap ini memetakan interrelationships dan interdependences antara respons teknis.

Mengembangkan technical matrix (Matriks Teknis). Matrik teknis bertujuan menentukan respons teknis mana yang ingin dikosentrasikan dan bagaimana jika dibandingkan dengan produk pesaing, matriks ini meliputi prioritized technical descriptor, benchmarking, GAP dan target.

\section{HASIL DAN PEMBAHASAN}

Penelitian ini menggunakan metode Servqual, maka atribut-atribut layanan dibreakdown ke dalam lima dimensi Servqual. Setelah melalui tahap penyebaran kuesioner pendahuluan ke-30 responsden dengan tujuan untuk lebih memfokuskan atribut-atribut layanan yang sesuai dengan kebutuhan pelanggan, maka atribut-atribut layanan terpilih yang digunakan dalam penelitian ini antara lain sebagai berikut.

Dimensi Tangibles (Bukti langsung). Meliputi sesuatu yang secara langsung dapat dilihat, dirasakan dan berwujud nyata meliputi penampilan fisik, perlengkapan/peralatan, dan sarana-sarana komunikasi yang digunakan. Kriteria yang termasuk meliputi:

A1. Kondisi armada (Kemutakhiran armada yang digunakan)

A2. Ketersediaan sarana kesehatan dan keselamatan (Kotak P3K, tabung pemadam kebakaran, dan lain-lain)
A3. Kerapihan penampilan driver (Pakaian, rambut, dan lain-lain)

A4. Ketepatan waktu penjemputan (Toleransi keterlambatan 15 menit)

Dimensi Reliability (Kehandalan). Kemampuan untuk memberikan/melaksanakan layanan yang telah dijanjikan secara akurat, dapat diandalkan dan memuaskan. Kriteria yang termasuk meliputi:

A5. Kenyamanan selama perjalanan (Jumlah seat sesuai jenis armada)

A6. Driver berpengalaman (Minimal 1 tahun)

A7. Kesederhanaan prosedur pemesanan travel via telepon (Maksimal 3 menit waktu pemesanan)

Dimensi Responsiveness (Daya tanggap). Daya tanggap berarti keinginan dan kesanggupan para staf untuk membantu konsumen dan penyediaan layanan yang cepat dengan tanggap. Kriteria yang termasuk meliputi:

A8. Kesediaan driver untuk membantu pelanggan (Memasukkan barang bawaan pelanggan ke dalam mobil)

A9. Kesigapan karyawan mengatasi complain pelanggan (Complain pelayanan)

A10. Konfirmasipemesanan travel(Konfirmasiulang 24 jam sebelum jadwal keberangkatan)

A11. Kesiapan untuk merespons permintaan pelanggan (Permintaan pelayanan)

Dimensi Assurance (Jaminan). Jaminan dapat mencakup kemampuan/pengetahuan, kesopanan dan sifat dapat dipercaya oleh konsumen yang dimiliki oleh para staf, sehingga dapat meyakinkan konsumen mengenai kualitas layanan yang diberikan. Kriteria yang termasuk meliputi:

A12. Keakuratan informasi yang diberikan karyawan (Tentang jadwal keberangkatan, driver, dll)

A13. Jaminan keamanan selama perjalanan (Bebas kecelakaan)

A14. Kesabaran driver dalam memberikan pelayanan (Selalu memberikan senyum tulus kepada pelanggan)

A15. Driver yang secara konsisten bersikap sopan terhadap pelanggan (Selalu mengucapkan salam kepada pelanggan, membukakan pintu mobil untuk pelanggan) 
Dimensi Emphaty. Empati meliputi komunikasi yang baik, sikap peduli, perhatian secara individu yang diberikan oleh pihak penyedia jasa kepada konsumen dalam memahami kebutuhannya. Kriteria yang termasuk meliputi:

A16. Keramahan karyawan (Operator, driver, dll)

A17. Karyawan selalu tanggap dengan apa yang diinginkan para pelanggan (Jenis musik yang diputar selama perjalanan, suhu AC)

A18. Kemudahan menghubungi dan mendapatkan informasi dari operator (Sekali telepon langsung terhubung dengan operator)

A19. Harga travel

A20. Pemberian snack dalam perjalanan (Roti dan air mineral)

Skor persepsi menunjukkan tingkat pelayanan yang telah diterima pelanggan terhadap atribut layanan selama menjadi pengguna jasa Travel "X". Data input yang digunakan adalah penilaian pelanggan terhadap atribut-atribut layanan dalam kuesioner. Skor persepsi terbesar menunjukkan bahwa responsden sudah cukup puas dengan pelayanan yang diberikan oleh Travel "X". Sebaliknya, skor persepsi terkecil menunjukkan responsden belum puas dengan pelayanan yang diberikan oleh Travel "X". Hasil dari pengolahan 20 atribut yang dipersepsikan oleh pelanggan Travel "X" diurutkan mulai dari skor terbesar hingga yang terkecil. Atribut-atribut tersebut antara lain sebagai berikut. Keramahan karyawan (operator, driver, dan lain-lain) $(\mathrm{A} 16)=4,867$. Kenyamanan selama perjalanan $(\mathrm{A} 5)=4,720$. Jaminan keamanan selama perjalanan $(\mathrm{A} 13)=4,693$. Kesabaran driver dalam memberikan pelayanan $(\mathrm{A} 14)=4,680$. Kerapian penampilan driver $(\mathrm{A} 3)=4,653$. Driver berpengalaman $(\mathrm{A} 6)=4,653$. Harga travel $(\mathrm{A} 19)=$ 4,653. Pemberian snack dalam perjalanan (roti dan air mineral $)(\mathrm{A} 20)=4,653$. Kesederhanaan prosedur pemesanan travel via telepon $(\mathrm{A} 7)=4,640$. Kondisi armada (kemutakhiran armada yang digunakan) $(\mathrm{A} 1)=4,613$. Kemudahan menghubungi dan mendapatkan informasi dari operator $(\mathrm{A} 18)=$ 4,613. Kesiapan untuk merespons permintaan pelanggan $(\mathrm{A} 11)=4,600$. Kesediaan driver untuk membantu pelanggan (A8) $=4,547$. Karyawan selalu tanggap dengan apa yang diinginkan para pelanggan $(\mathrm{A} 17)=4,520$. Driver yang secara konsisten bersikap sopan terhadap pelanggan
$(\mathrm{A} 15)=3,960$. Konfirmasi pemesanan travel $(\mathrm{A} 10)=3,360$. Ketersediaan sarana kesehatan dan keselamatan (kotak P3K, tabung pemadam kebakaran, dan lain-lain) (A2) $=3,227$. Kesigapan karyawan mengatasi complain pelanggan (A9) = 3,133 . Ketepatan waktu penjemputan $(\mathrm{A} 4)=2,733$. Keakuratan informasi yang diberikan karyawan $(\mathrm{A} 12)=2,453$.

Berdasarkan hasil perhitungan skor ekspektasi, didapatkan skor tingkat kepentingan pelanggan terhadap atribut layanan. Data input yang digunakan adalah penilaian pelanggan terhadap atribut-atribut layanan dalam kuesioner. Mean untuk tiap atribut sengaja diurutkan dari yang paling besar ke yang paling kecil untuk mengetahui atribut mana yang paling dipentingkan oleh pelanggan. Hasilnya adalah sebagai berikut. Kemudahan menghubungi dan mendapatkan informasi dari operator $(\mathrm{A} 18)=4,707$. Harga travel $(\mathrm{A} 19)=4,693$. Kesigapan karyawan mengatasi complain pelanggan $(\mathrm{A9})=4,680$. Ketersediaan sarana kesehatan dan keselamatan (kotak P3K, tabung pemadam kebakaran, dan lain-lain) $(\mathrm{A} 2)=$ 4,653. Keramahan karyawan (operator, driver, dll) $(\mathrm{A} 16)=4,640$. Pemberian makanan ringan dalam perjalanan (roti dan air mineral) $(\mathrm{A} 20)=$ 4,640. Keakuratan informasi yang diberikan karyawan $(\mathrm{A} 12)=4,627$. Jaminan keamanan selama perjalanan $(\mathrm{A} 13)=4,627$. Kenyamanan selama perjalanan $(\mathrm{A} 5)=4,613$. Kesederhanaan prosedur pemesanan travel via telepon $(\mathrm{A} 7)=$ 4,613. Kesabaran driver dalam memberikan pelayanan $(\mathrm{A} 14)=4,587$. Ketepatan waktu penjemputan $(\mathrm{A} 4)=4,573$. Driver yang secara konsisten bersikap sopan terhadap pelanggan $(\mathrm{A} 15)=4,533$. Konfirmasi pemesanan travel $(\mathrm{A} 10)=4,520$. Kesiapan untuk merespons permintaan pelanggan $(\mathrm{A} 11)=4,520$. Driver berpengalaman $(\mathrm{A} 6)=4,507$. Kerapihan penampilan driver $(\mathrm{A} 3)=4,493$. Kondisi armada (kemutakhiran armada yang digunakan) $(\mathrm{A} 1)=4,480$. Kesediaan driver untuk membantu pelanggan $(\mathrm{A} 8)=4,480$. Karyawan selalu tanggap dengan apa yang diinginkan para pelanggan $(\mathrm{A} 17)=4,467$.

Berdasarkan perhitungan skor Servqual, dari 20 atribut layanan terdapat delapan atribut yang memiliki nilai gap negatif (-). Nilai negatif ini menunjukkan bahwa harapan yang diinginkan 
pelanggan Travel "X" lebih besar dibandingkan persepsi pelayanan yang ada saat ini atau dengan kata lain pihak Travel "X" belum maksimal dalam memenuhi harapan pelanggan. Atribut-atribut yang bernilai negatif antara lain sebagai berikut: Keakuratan informasi yang diberikan karyawan $(\mathrm{A} 12)=-2,174$, Ketepatan waktu penjemputan (A4) $=-1,840$, Kesigapan karyawan mengatasi complain pelanggan (A9) $=-1,547$, Ketersediaan sarana kesehatan dan keselamatan (kotak P3K, tabung pemadam kebakaran, dll) (A2) $=-1,426$, Konfirmasi pemesanan travel (A10) $=-1,160$, Driver yang secara konsisten bersikap sopan terhadap pelanggan $(\mathrm{A} 15)=-0,573$, Kemudahan menghubungi dan mendapatkan informasi dari operator $(\mathrm{A} 18)=-0,094$, Harga travel $(\mathrm{A} 19)=$ $-0,040$.

Untukgap atributyang bernilai positif(+) maka tidak ada permasalahan terhadap bentuk pelayanan tersebut. Atribut-atribut yang dimaksud antara lain sebagai berikut. Pemberian makanan ringan dalam perjalanan (roti dan air mineral) $(\mathrm{A} 20)=$ 0,013. Kesederhanaan prosedur pemesanan travel via telepon $(\mathrm{A} 7)=0,027$. Karyawan selalu tanggap dengan apa yang diinginkan para pelanggan $(\mathrm{A} 17)=$ 0,053. Jaminan keamanan selama perjalanan $(\mathrm{A} 13)=0,066$. Kesediaan driver untuk membantu pelanggan $(\mathrm{A} 8)=0,067$. Kesiapan untuk merespons permintaan pelanggan $(\mathrm{A} 11)=0,080$. Kesabaran driver dalam memberikan pelayanan $(\mathrm{A} 14)=$ 0,093 . Kenyamanan selama perjalanan $(\mathrm{A} 5)=$ 0,107 . Kondisi armada (kemutakhiran armada yang digunakan) $(\mathrm{A} 1)=0,133$. Driver erpengalaman $(\mathrm{A} 6)=0,146$. Kerapihan penampilan driver $(\mathrm{A} 3)=$ 0,160 . Keramahan karyawan (operator, driver, dan lain-lain) $(\mathrm{A} 16)=0,227$.

Karena penelitian ini menggabungkan kelebihan metode Servqual dan QFD, maka dalam menyusun daftar matriks WHATs dilakukan seleksi jumlah customer needs dengan memperhatikan skor gap. Atribut layanan yang bernilai negatif (-) akan dimasukkan ke dalam komponen customer needs.

Berdasarkan hasil perhitungan skor kuesioner yang dilakukan sebelumnya mengenai tingkat kepentingan, diperoleh nilai kepentingan konsumen (important to customer) terhadap masing-masing atribut layanan Travel "X", yaitu sebagai berikut: Keakuratan informasi yang diberikan karyawan
$(\mathrm{A} 12)=4,627$, Ketepatan waktu penjemputan $(\mathrm{A} 4)=4,573$, Kesigapan karyawan mengatasi complain pelanggan $(\mathrm{A} 9)=4,680$, Ketersediaan sarana kesehatan dan keselamatan (kotak P3K, tabung pemadam kebakaran, dan lain-lain) (A2) = 4,653 , Konfirmasi pemesanan travel (A10) = 4,520 , Driver yang secara konsisten bersikap sopan terhadap pelanggan $(\mathrm{A} 15)=4,533$, Kemudahan menghubungi dan mendapatkan informasi dari operator $(\mathrm{A} 18)=4,707$, Harga travel $(\mathrm{A} 19)=$ 4,693 .

Nilai kepuasan konsumen (customer satisfaction performance) terhadap atribut layanan Travel "X" diperoleh dari hasil perhitungan skor kuesioner yang dilakukan sebelumnya mengenai tingkat kepuasan. Nilai untuk masing-masing atribut adalah sebagai berikut. Keakuratan informasi yang diberikan karyawan $(\mathrm{A} 12)=2,453$. Ketepatan waktu penjemputan $(\mathrm{A} 4)=2,733$. Kesigapan karyawan mengatasi complain pelanggan $(\mathrm{A} 9)=3,133$. Ketersediaan sarana kesehatan dan keselamatan (kotak P3K, tabung pemadam kebakaran, dan lainlain) $(\mathrm{A} 2)=3,227$. Konfirmasi pemesanan travel $(\mathrm{A} 10)=3,360$. Driver yang secara konsisten bersikap sopan terhadap pelanggan $(\mathrm{A} 15)=3,960$. Kemudahan menghubungi dan mendapatkan informasi dari operator $(\mathrm{A} 18)=4,613$. Harga travel $(\mathrm{A} 19)=4,653$.

Nilai kepuasan konsumen terhadap atribut layanan Travel "Y" sebagai travel pesaing diperoleh darihasilperhitunganskorkuesioneryangdilakukan sebelumnya mengenai tingkat kepuasan pesaing (Competitive Satisfaction Performance). Nilai untuk masing-masing atribut adalah sebagai berikut: Keakuratan informasi yang diberikan karyawan $(\mathrm{A} 12)=3,160$, Ketepatan waktu penjemputan $(\mathrm{A} 4)=4,387$, Kesigapan karyawan mengatasi complain pelanggan $($ A9) $=4,013$, Ketersediaan sarana kesehatan dan keselamatan (kotak P3K, tabung pemadam kebakaran, dan lain-lain) $(\mathrm{A} 2)=4,573$, Konfirmasi pemesanan travel $(\mathrm{A} 10)=$ 4,720 , Driver yang secara konsisten bersikap sopan terhadap pelanggan $(\mathrm{A} 15)=4,560$, Kemudahan menghubungi dan mendapatkan informasi dari operator $(\mathrm{A} 18)=4,867$, Harga travel $(\mathrm{A} 19)=$ 4,813 .

Perbandingan customer satisfaction tiap atribut dari kedua travel. (a) Atribut keakuratan informasi yang diberikan karyawan; Nilai kepuasan yang diperoleh dari Travel "X" adalah 
2,453 lebih rendah dari nilai yang diperoleh dari Travel "Y", yaitu 3,160. (b) Atribut ketepatan waktu penjemputan; Nilai kepuasan yang diperoleh dari Travel "X" adalah 2,733 lebih rendah dari nilai yang diperoleh dari Travel "Y", yaitu 4,387. (c) Atribut kesigapan karyawan mengatasicomplain pelanggan; Nilai kepuasan yang diperoleh dari Travel "X" adalah 3,133 lebih rendah dari nilai yang diperoleh dari Travel "Y", yaitu 4,013. (d) Atribut ketersediaan sarana kesehatan dan keselamatan (kotak P3K, tabung pemadam kebakaran, dan lainlain); Nilai kepuasan yang diperoleh dari Travel "X" adalah 3,227 lebih rendah dari nilai yang diperoleh dari Travel "Y", yaitu 4,573. (e) Atribut konfirmasi pemesanan travel; Nilai kepuasan yang diperoleh dari Travel "X" adalah 3,360 lebih rendah dari nilai yang diperoleh dari Travel "Y", yaitu 4,720. (f) Atribut driver yang secara konsisten bersikap sopan terhadap pelanggan; Nilai kepuasan yang diperoleh dari Travel "X" adalah 3,960 lebih rendah dari nilai yang diperoleh dari Travel "Y", yaitu 4,560. (g) Atribut kemudahan menghubungi dan mendapatkan informasi dari operator; Nilai kepuasan yang diperoleh dari Travel "X" adalah 4,613 lebih rendah dari nilai yang diperoleh dari Travel "Y", yaitu 4,867. (h) Atribut harga travel; Nilai kepuasan yang diperoleh dari Travel "X" adalah 4,653 lebih rendah dari nilai yang diperoleh dari Travel "Y", yaitu 4,813.

Tingkat performansi yang hendak dicapai ditentukan berdasarkan tingkat kepentingan atribut dan tingkat kepuasan pelanggan terhadap pelayanan yang telah diberikan oleh pihak Travel "X" beserta pesaingnya. Penentuan nilai goal ini dipilih nilai yang tertinggi diantara tingkat kepentingan, tingkat kepuasan konsumen terhadap pelayanan Travel "X" dan tingkat kepuasan konsumen terhadap pelayanan Travel "Y" sebagai pesaing. Kenapa dalam penentuan goal diambil nilai tertinggi, dengan tujuan untuk memperoleh target yang maksimal.

Nilai goal untuk semua atribut kebutuhan pelanggan, terdapat 4 (empat) atribut keinginan konsumen dari tingkat kepuasan terhadap pesaing (Travel "Y") yang digunakan sebagai nilai goal yaitu atribut konfirmasi pemesanan travel, driver yang secara konsisten bersikap sopan terhadap pelanggan, kemudahan menghubungi dan mendapatkan informasi dari operator serta harga travel. Untuk mencapai nilai goal yang sudah dicapai pesaing dibutuhkan suatu usaha peningkatan. Sedangkan untuk atribut lainnya, dimana nilai kepuasannya masih di bawah tingkat kepentingan, yaitu keakuratan informasi yang diberikan karyawan, ketepatan waktu penjemputan, kesigapan karyawan mengatasi complain pelanggan serta ketersediaan sarana kesehatan dan keselamatan (kotak P3K, tabung pemadam kebakaran, dan lain-lain).

Rasio peningkatan untuk masing-masing atribut menunjukkan bobot kesulitan untuk melakukan peningkatan. Rasio peningkatan paling tinggi dialami oleh atribut keakuratan informasi yang diberikan karyawan yaitu sebesar 1,886. Atribut ini memiliki nilai kepentingan yang tinggi sebesar 4,627 dan nilai kepuasan yang rendah yakni 2,453. Hal ini menunjukkan bahwa Travel "X" harus melakukan usaha cukup keras untuk melakukan peningkatan performansi (pemenuhan kepuasan konsumen) yang berkaitan dengan atribut ini. Urutan berikutnya rasio peningkatan paling tinggi kedua dialami oleh atribut ketepatan waktu penjemputan, yaitu sebesar 1,673. Atribut ini memiliki nilai kepentingan sebesar 4,573 dan nilai kepuasan hanya sebesar 2,733. Begitu pula pada atribut selanjutnya. Jadi apabila nilai Improvement Ratio semakin besar maka diperlukan usaha peningkatan, sebaliknya jika nilai Improvement Ratio nya semakin kecil maka nilai performansinya cukup dipertahankan.

Nilai sales point dari hasil diskusi tim pengembangmenunjukkanbahwaatributkesigapan karyawan mengatasi complain pelanggan, kemudahan menghubungi dan mendapatkan informasi dari operator serta harga travel mempunyai nilai sales point tertinggi, yaitu 1.5. Jadi apabila kepuasan konsumen untuk atribut ini dapat dipenuhi maka nilai penjualan diharapkan akan mengalami peningkatan tajam. Sedangkan atribut keakuratan informasi yang diberikan karyawan, ketepatan waktu penjemputan, ketersediaan sarana kesehatan dan keselamatan (kotak P3K, tabung pemadam kebakaran, dan lainlain), serta driver yang secara konsisten bersikap sopan terhadap pelanggan. nilai sales point sebesar 1.2 dan atribut konfirmasi pemesanan travel mimiliki nilai sales point sebesar 1.0. Jadi, semakin besar nilai sales point, maka tingkat penjualan akan 
meningkat apabila atribut ini dapat memenuhi kepuasan pelanggan.

Nilai raw weight berkaitan erat dengan tingkat kepuasan konsumen, besarnya usaha yang diperlukan untuk mengimplementasikan peningkatan atribut tersebut dan nilai potensial penjualannya. Semakin besar nilai raw weight, maka atribut tersebut semakin menjadi perhatian utama bagi tim pengembang kualitas, untuk dikembangkan terlebih dahulu. Hasil pengolahan data nilai raw weight menunjukkan bahwa atribut kesigapan karyawan mengatasi complain pelanggan mempunyai nilai tertinggi, yaitu 10,488. Nilai raw weight terbesar kedua terletak pada atribut keakuratan informasi yang diberikan karyawan 10,472 dan nilai terbesar ketiga terletak pada atribut ketepatan waktu penjemputan dengan nilai 9,181. Jadi konsentrasi tim pengembang kualitas harus lebih banyak diarahkan pada atribut kesigapan karyawan mengatasi complain pelanggan. Untuk atribut lainnya juga menjadi perhatian tim pengembang kualitas berdasarkan urutan besarnya nilai raw weight.

Besarnya nilai dari normalized raw weight didapatkan dari nilai raw weight (NRW). Nilai normalized raw weight menunjukkan besarnya kontribusi atribut tersebut terhadap pemenuhan semua keinginan konsumen. Semakin besar nilai NRW maka semakin besar pula kontribusi atribut tersebut untuk memenuhi keinginan wisatawan. Urutan nilai NRW adalah sama dengan RW. Nilai NRW lebih mudah digunakan untuk melakukan perhitungan misalnya penentuan nilai prioritas respons teknis.

Analisis technical respons (Matrik HOWs). Semua item respons teknis dimunculkan untuk memenuhi tingkat kepuasan konsumen terhadap setiap atribut dalam customer needs. Atribut keakuratan informasi yang diberikan karyawan memunculkan respons teknis berupa pelatihan karyawan, seperti pada House of Quality yang telah dihasilkan. Hal ini bisa dilihat dari hubungannya.

Analisis hubungan antara matriks WHATs dan HOWs (Relationship Matrix). Hubungan antara atribut-atribut dalam Customer Needs dengan respons teknis dapat dinyatakan dengan simbol-simbol yang menunjukkan seberapa kuat hubungan pengaruh respons teknis untuk memenuhi kebutuhan konsumen tersebut. (a) Atribut keakuratan informasi yang diberikan karyawan; Atribut ini mempunyai hubungan kuat dengan perbaikan komunikasi antardepartemen dalam perusahaan. Atribut ini juga memiliki hubungan yang lemah dengan pelatihan karyawan serta mengupdate informasi-informasi penting pada website perusahaan. (b) Atribut ketepatan waktu penjemputan; Atribut ini mempunyai hubungan kuat dengan perbaikan sistem penjadwalan penjemputan. Atribut ini juga memiliki hubungan yang sedang dengan pelatihan karyawan dan memiliki hubungan yang lemah dengan perbaikan komunisi antardepartemen dalam perusahaan. (c) Atribut kesigapan karyawan mengatasi complain pelanggan; Atribut ini mempunyai hubungan yang kuat dengan pelatihan karyawan dan menyediakan nomor telepon khusus pengaduan pelayanan (complain). (d) Atribut ketersediaan sarana kesehatan dan keselamatan (kotak P3K, tabung pemadam kebakaran, dan lain-lain); Atribut ini memiliki hubungan yang kuat dengan melengkapi semua armada dengan saranan kesehatan dan keselamatan. (e) Atribut konfirmasi pemesanan travel; Atribut ini memiliki hubungan yang kuat dengan konfirmasi pemesanan travel maksimal 1 hari sebelum keberangkatan. Atribut ini juga memiliki hubungan yang lemah dengan pemisahan tugas operator pelayanan travel dengan operator pelayanan tiket pesawat serta penambahan operator pelayanan travel. (f) Atribut driver yang secara konsisten bersikap sopan terhadap pelanggan; Atribut ini memiliki hubungan yang kuat dengan pelatihan karyawan serta inspeksi secara rutin terhadap driver. Atribut ini juga memiliki hubungan yang sedang dengan menyediakan nomor telepon khusus pengaduan pelayanan (complain). (g) Atribut kemudahan menghubungi dan mendapatkan informasi dari operator; Atribut ini memiliki hubungan yang kuat dengan pemisahan tugas operator pelayanan travel dengan operator pelayanan tiket pesawat serta penambahan operator pelayanan travel. (h) Atribut harga travel; Atribut ini memiliki hubungan yang sedang dengan pemberian diskon harga travel terhadap pelanggan yang juga membeli tiket pesawat di Travel "X" 
$\begin{array}{ccc}\text { Analisis hubungan antar matriks } & \text { HOWs } \\ \text { (Technical Correlation). Korelasi teknis }\end{array}$ antarrespons teknis ditunjukan dengan menggunakan simbol-simbol tertentu. Berdasarkan data yang terkumpul pada matriks korelasi teknis tampak sebagai berikut: (a) Pelatihan karyawan, mempunyai pengaruh positif sangat kuat dengan: perbaikan komunikasi antardepartemen dalam perusahaan, perbaikan sistem penjadwalan penjemputan, konfirmasi pemesanan travel maksimal 1harisebelumkeberangkatan, pemisahan tugas operator pelayanan travel dengan operator pelayanan tiket pesawat, penambahan operator pelayanan travel, mengupdate informasi-informasi penting pada website perusahaan, (b) Perbaikan komunikasi antar departemen dalam perusahaan berpengaruh positif cukup kuat dengan: perbaikan sistem penjadwalan penjemputan, inspeksi secara rutin terhadap driver, (c) Perbaikan sistem penjadwalan penjemputan, berpengaruh positif cukup kuat dengan: pemisahan tugas operator pelayanan travel dengan operator pelayanan tiket pesawat, penambahan operator pelayanan travel, (d) Konfirmasi pemesanan travel maksimal 1 hari sebelum keberangkatan, berpengaruh positif sangat kuat dengan: pemisahan tugas operator pelayanan travel dengan operator pelayanan tiket pesawat, penambahan operator pelayanan travel, (e) Pemisahan tugas operator pelayanan travel dengan operator pelayanan tiket pesawat, berpengaruh positif sangat kuat dengan Penambahan operator pelayanan travel.

Analisis Prioritas (Prioritized Technical Descriptor) dan Contribution. Nilai prioritas respons teknis ini menunjukkan besarnya kontribusi respons teknis tersebut, untuk memenuhi keinginan konsumen. Semakin besar nilai prioritas ini maka semakin besar pula kontribusi respons teknis tersebut dalam memenuhi kepuasan konsumen. Dari rumah kualitas dapat dianalisis nilai prioritasnya, namun terlebih dahulu harus diketahui dan diidentifikasi matrik hubungannya. Nilai prioritas respons teknis ini menunjukkan besarnya kontribusi respons teknis tersebut untuk untuk memenuhi keinginan konsumen. Semakin besar nilai prioritas ini maka semakin besar pula kontribusi respons teknis tersebut dalam memenuhi kepuasan konsumen. Dalam hal ini didapatkan bahwa respons teknis pelatihan karyawan mempunyai nilai prioritas yang terbesar, yaitu 121,786 dan kontribusi ternormalisasinya adalah 0,234. Hal ini menunjukkan bahwa respons teknis pelatihan karyawan mempunyai kontribusi sebesar sekitar 23,4\% untuk memenuhi keseluruhan kepuasan konsumen.

Pada tahap ini tim pengembang kualitas melakukan diskusi untuk menentukan tingkat performansi respons teknis yang dimiliki oleh Travel "X" dibandingkan dengan Travel "Y". Setelah membuat House of Quality maka kita bisa membandingkan performansi respons teknis yang dimiliki Travel "X" dengan Travel "Y" sebagai pesaingnya. Kemudian kita bisa menentukan target tingkat performansi respons teknis yang dimiliki apakah ditargetkan tetap atau bahkan mengalami peningkatan. Berdasarkan hasil pembandingan benchmarking dapat dilihat bahwa nilai performansi respons teknis pesaing lebih tinggi dari Travel "X" sehingga dibutuhkan usaha keras untuk meningkatkannya.

Target tingkat performansi respons teknis yang diinginkan oleh tim QFD mengarah pada peningkatan performansi respons teknis yang sudah dimiliki. Dari keseluruhan respons teknis, semuanya ditargetkan untuk ditingkatkan

Respons teknis yang diprioritaskan untuk dilakukan oleh perusahaan adalah melakukan pelatihan karyawan. Nilai prioritasnya mencapai 121,786 atau mempunyai kontribusi sebesar 23,4\% terhadap pemenuhan kebutuhan pelanggan. Menurut Studi yang dilakukan oleh Ferrinadewi dan Djati (2004), karyawan memiliki peran yang penting bagi keberhasilan organisasi. Ada beberapa usulan pelatihan yang bisa dilakukan perusahaan seperti (1) Magang/apprenticeship training; Magang adalah suatu pembekalan pegawai dengan cara belajar langsung dengan senior dan diawasi oleh para pakar atau ahlinya. (2) Learning by doing/ on the job training/Bekerja Sambil Belajar; On the job training adalah suatu bentuk pembekalan yang dapat mempercepat proses pemindahan pengetahuan dan pengalaman kerja/transfer knowledge dan para karyawan senior ke junior. Pelatihan ini langsung menerjunkan pegawai bekerja sesuai dengan job description/jobdesc masing-masing di bawah supervisi/pengawasan penyelia atau karyawan senior. (3) Vestibule training; Vestibule training adalah memberikan 
pelatihan semacam kursus yang dijalankan di luar lingkungan kerja.

Carrell et al., Nur Tanjung (2008) menyatakan ada tujuh maksud utama program pelatihan dan pengembangan, yaitu memperbaiki kinerja, meningkatkan keterampilan karyawan, menghindari keusangan manajerial, memecahkan permasalahan, orientasi karyawan baru, persiapan promosidankebijakanmanajerial,sertamemberikan kepuasan untuk kebutuhan pengembangan personal. Jadi yang perlu dilakukan perusahaan untuk melakukan perbaikan adalah dengan cara memberikan pelatihan terhadap karyawan baru ataupun karyawan lama.

\section{SIMPULAN}

Atribut-atribut pelayanan yang perlu diperbaiki dapat dilihat dari atribut-atribut yang memiliki nilai gap negatif dan jumlahnya masih cukup banyak, besar persentasenya mencapai $40 \%$ atau 8 atribut pelayanan. Hal ini mengindikasikan bahwa kualitas yang diterima masih belum memenuhi harapan pelanggan Travel "X". Atribut-atribut yang menjadi prioritas utama untuk ditingkatkan yaitu: keakuratan informasi yang diberikan karyawan, ketepatan waktu penjemputan, kesigapan karyawan mengatasi complain pelanggan, ketersediaan sarana kesehatan dan keselamatan (kotak P3K, tabung pemadam kebakaran, dan lain-lain). konfirmasi pemesanan travel, driver yang secara konsisten bersikap sopan terhadap pelanggan, kemudahan menghubungi dan mendapatkan informasi dari operator, harga travel.
Berdasarkan nilai kontribusi respons teknis terhadap pemenuhan kepuasan pelanggan, prioritas perbaikan utama yang harus dilakukan oleh Travel "X" adalah melakukan pelatihan karyawan. Usulan jenis-jenis pelatihan yang dapat dilakukan seperti: magang/apprenticeship training, learning by doing/on the job training/bekerja sambil belajar dan vestibule training.

\section{DAFTAR PUSTAKA}

Amin, W., 1992. Manajemen Mutu Terpadu. Jakarta: Rineka Cipta.

Cohen, L., 1995. Quality Function Deployment: How to Make QFD Work for You. Massachusets: AddisonWesley Publishing Company.

Gasperz, V., 1997. Manajemen Kualitas dalam Industri Jasa. Jakarta: Gramedia.

Gasperz, V., 2005. Total Quality Management. Jakarta: PT. Gramedia Pustaka Utama.

Hal-hal Penting dalam Training - Indonesian Human Resource Management, 2007. Oktober 2008. (www. portalhr.com/Tips.mht/)

Jiang, J.J., Klein, G., and Carr, C.L., 2002. Measuring Information System Service Quality: SERVQUAL from the Other Side. MIS Quarterly, 26(2): 145-6.

Kottler, P., 1994. Manajemen Pemasaran: Analisis, Perencanaan, Implikasi, Jilid 1 dan 2. Jakarta: Pehallindo.

Lupiyoadi, R., 2001. Manajemen Pemasaran Jasa (Teori dan Praktik). Jakarta: Salemba Empat.

Nur Tanjung, 2008. Macam dan Jenis Pelatihan - Training bagi Pegawai - Karyawan Baru Non Manajerial Manajemen Sumber Daya Manusia. (www. organisasi.org/mht) 